\title{
Relationship between Proactive Personality Traits and Transformational Leadership Style among Workers: Moderating Role of Psychological Empowerment
}

\author{
Iloke, Stephen E. ${ }^{1}$, Joe-Akunne, Chiamaka O. ${ }^{2}$, Joe-Akunne, Ikenna G. ${ }^{3}$, Ezeh, Leonard N. ${ }^{4}$ \\ ${ }^{1,2,4}$ Department of Psychology, Faculty of Social Science, Nnamdi Azikiwe University, Awka, Anambra State, Nigeria \\ ${ }^{3}$ Department of Political Science, Faculty of Social Science, Nnamdi Azikiwe University, Awka, Anambra State, Nigeria
}

\begin{abstract}
The purpose of this study is to investigate relationship between proactive personality traits and transformational leadership style among workers: moderating role of psychological empowerment. The study was guided by two hypotheses. A total of 112 participants were selected for the study using simple random and convenience sampling technique. The participants were all non-teaching staff of Nnamdi Azikiwe University, Awka, Anambra-Nigeria. The participants comprised of 62 males and 50 females with a mean age of 32.51 and standard deviation of 8.68. Their age ranged from 18 to 51 years. The study made use of three instruments namely: proactive personality scale by Bateman \& Crant (1993), transformational leadership inventory by Podsakoff (1990) and psychological empowerment scale by Spreitzer (1995). The study is a survey study which adopted the correlational design; consequently multiple linear regressions were used as a statistical tool for data analysis. The result showed that proactive personality positively and significantly correlated with transformational leadership style at $r=.33, p<.01$. Furthermore, the interaction effect between proactive personality trait, all the dimensions of psychological empowerment accounted for negative significant variance than just proactive personality and transformational leadership styles alone, $\mathrm{R}^{2}$ change $=.07$ at $\mathrm{p}<.01$. Based on the findings of the study, the researchers recommended that Organizations are advised to employ transformational leadership styles as it is also a way of empowering the employees psychologically.
\end{abstract}

KEYWORDS: Proactive Personality Traits, Transformational Leadership \& Psychological Empowerment

\section{INTRODUCTION}

The common problem faced by organizations in Nigeria and to an extent, Africa is related to human resource management and development, especially as many of the unsatisfied employees make it difficult for organizations to achieve their targets. Motivation in organizations can be enhanced with the kind of leadership that devotes its attention to the problems faced by its followers by encouraging them to achieve their goals. This is supported by Rivai (2011), where he saw leadership as a process of management; directing and influencing work-related activities of its followers. To Rivai (2011), leadership is also the process of influencing and determining organizational goals, motivating followers' behaviors to achieve set goals affecting group and culture. Based on the afore-narrated, there is need for organizations to increase their knowledge and be broad based in their awareness about the environment, and create wide organizational changes for survival and development. In this sense, the role of leaders who want to move the organization towards the future is to recognize the environmental needs and facilitate appropriate changes, in which case it becomes more evident that such leaders are transformational in nature. The leaders can strengthen staff understanding and injustice and thus, improve the quality of work life in the organization.

The importance of transformational leadership style in organizations cannot be overemphasized. This is because the transformational leader constantly looks for potential motives in followers and aims to draw the followers' attention to superior needs and conversion of individual interests towards promoting and achieving organizational goals. According to Farazja \& Khademi (2011), transformational leadership style is highly conscious, morally engaging and even a spiritual process that provides developmental cubicle for organizations, through a reliable and equal power leadership. Transformational leaders explain organization's future prospects and provide the model which is consistent with the prospects, improve acceptance of group goals, provide a wide range of support for individuals in the organization, and this in turn actualizes organizational goals (Farazja \& Khademi 2011). More so, transformational leadership style could positively be said to bring about psychological empowerment in organizations. This is 


\title{
International Journal of Current Science Research and Review
}

\author{
ISSN: 2581-8341
}

\section{Volume 04 Issue 09 September 2021}

DOI: 10.47191/ijcsrr/V4-i9-12, Impact Factor: 5.825

because when employees are guided and directed in affective manners, they are invariably being empowered for the general wellbeing of the organization.

Thus, psychological empowerment is a vital concept originating from industrial and organizational psychology. It can be defined as an intrinsic task motivation reflecting sense of self control in relation to one's work and an active engagement with one's work role. Empowerment is seen as a process of strengthening individuals' feelings of their own effectiveness among other members of an organization (Conger \& Kanungo, 1988). Considering the advancement of science and technology together with increase in global competition, it is recognized that psychological empowerment is highly crucial for organizational effectiveness. More so, when employees perceive that their job requirements and contributions are meaningful, they will spend more efforts in order to understand the problems from multiple perspectives and search for multiple solutions, using information from varied and numerous sources (Ergeneli, Ari \& Metin, 2007; Gilson, \& Shalley, 2004; Zhang \& Bartol, 2010).

Amundsen \& Marinsen (2015) hinted that when employees are being psychologically empowered, their satisfaction level tends to boost. In the same manner, their belief of personal efficacies and ability to perform tasks are likely to result in higher satisfaction levels (Spreitzer et al; 1997; Hartline \& Ferrell, 1996). Individuals are more likely to be satisfied than others since self-determination is a key contributor to intrinsic motivation (Spreitzer, 1997). Leaders encourage their followers to accomplish specific goals that represent the expectations of themselves and their followers, taking into account their values and their passion (Burns, 1979). Sharing the same view, Provitera \& Ghasabeh, (2017) saw transformational leadership as relating to the theory of trait. Thinkers who depend on the theory of trait believe a person should be born; just anyone cannot be perfect later. Transformational leaders let their followers have input through psychological empowerment which would bring proactivity and so, the followers feel more valued and the relationship becomes more established (Provitera \& Ghasabeh, 2017). This energizes and motivates their subordinates to improve their possession of the shared vision and realize that vision. Morale increases and team members in get empowered to develop their leadership abilities (Rolfe, 2011). From these explanations, it is important that leaders ensure that their followers contribute their vision and ideas in order to realize more preferable results.

Therefore, in order to facilitate industrial and organizational harmony in work places, there is need for organizations to promote proactivity among employees. Kirkman \& Rosen, (1999) and Williams, et al (2010) have suggested that leaders can also be transformational in their leadership when they empower employees, enhance their capabilities, and provide them with autonomy. However, being proactive in making changes in organizations is very challenging and demanding in many aspects because it takes a lot of efforts for an organization to identify potential opportunities, search for an alternative ways to improve and most importantly, to coordinate within and outside organization's activities, and to achieve collective action and also affect changes (Bauer \& Frese, 2003; Williams, et al, 2010).

Bateman \& Crant (1993) introduced the proactive disposition as a construct that identifies differences among people in the extent to which they take action to influence their environments. They described individuals' with a prototypical proactive personality as people who are relatively unconstrained by situational factors and who effects environmental changes. Proactive people are those that identify opportunities and acts on them, show initiative, take actions and persist until meaningful changes occur. In contrast, people who are not proactive exhibit the opposite patterns. But it is important to note that as people progress in the organization, more dynamic and decentralized, proactive behavior and initiatives become even more critical determinants of organizational success. For example, as new forms of management are introduced to ensure organizational efficiency and minimize the surveillance function, organizations will increasingly rely on employees' personal initiatives to identify and solve problems (Frese, Fay, Hilburger, Leng \& Tag, 1997). Although, proactive behavior and personality has received considerable and scholarly research attention over the years, it has however not emerged as an integrated research stream that seeks the knowledge of its relationship on other positive psychological constructs as transformational leadership style and psychological empowerment.

In this study, transformational leadership style has been proposed as the root element that promotes effective organizational work environment because there is special attention to the development of empowering leader-followership relationship. Nonetheless, the relationship between psychological empowerment and proactive personality among workers is yet to be extensively examined and probed. However, it is not yet very clear as to whether psychological empowerment will moderate the relationships that proactive personality and transformational leadership style share. The association of proactive personality and leadership style and the role psychological empowerment in turn plays in promoting or discouraging them have not been examined. This study however attempts to explore proactive personality traits and transformational leadership style: moderating role of psychological empowerment. 


\section{International Journal of Current Science Research and Review}

ISSN: 2581-8341

Volume 04 Issue 09 September 2021

DOI: 10.47191/ijcsrr/V4-i9-12, Impact Factor: 5.825

Proactive personality dispositions and transformational leadership style are considered to be uniquely important in this our present day ever dynamic and competitive work organizations. It is these expectations that led to the formulation of the hypotheses that guided the study.

\section{THEORETICAL FRAMEWORK}

Maslow's Theory of Hierarchical Needs (Abraham Maslow, 1943)

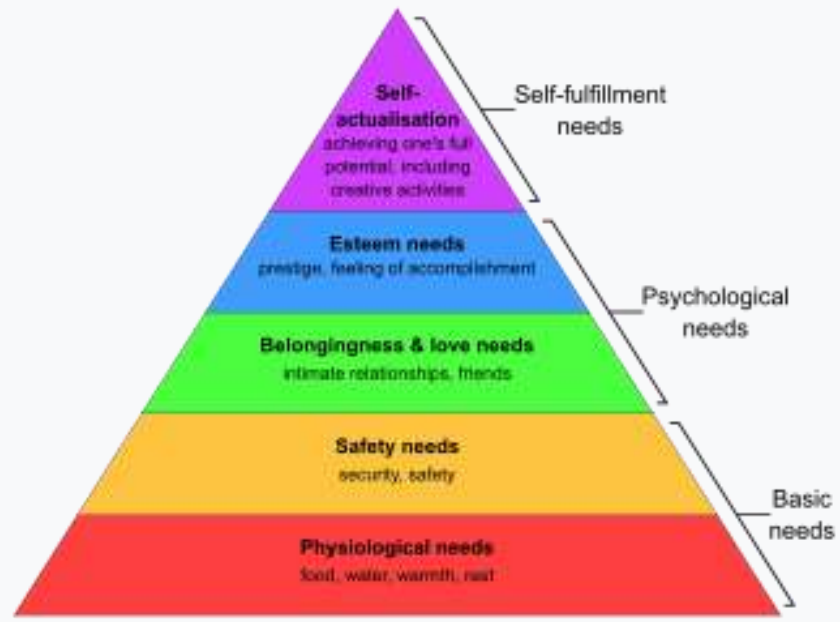

Maslow's hierarchy of needs, represented as a pyramid with the more basic needs at the bottom

The basis of this Maslow's hierarchical theory of human needs is that human beings are motivated by unsatisfied needs, and that certain lower needs need to be satisfied before higher needs can be satisfied. Maslow's posits that there are general needs (ranging from physiological, safety, and love to esteem) which have to be distinctively and satisfactorily fulfilled before a person is able to act unselfishly. These needs were tagged "deficiency needs." While a person is motivated to fulfill these basal desires, they continue to move towards growth, and eventually self-actualization. The satisfaction of needs is quite healthy, while preventing their gratification most often than not will make people ill or engage an anti-social behavior. As a result, for adequate motivation of the masses, it is important that leaders understand which needs are active for the people they govern. Aligning with Abraham Maslow in his unique line of thought, it is necessary to point out that his model indicates that basic but low-level needs such as physiological requirements and safety must be satisfied before higher-level needs such as self-fulfillment are pursued. As depicted in the hierarchical diagram of Maslow shown above, sometimes called 'Maslow's Needs Pyramid', when a need is satisfied it no longer motivates and the next higher need takes its place. Implications of need hierarchy for empowerment If Maslow's theory holds, there are some important leadership implications to enhance people's motivation and eventual empowerment.

- Physiological Needs: are the basic needs of feeding, accommodation, salaries/wages that are perceived by the employees to be sufficient for the purchase of the essentials of life.

- Safety Needs: are needs to for a safe environment to live in, freedom from threats, and relative security. • Social Needs: Create a feeling of acceptance, belonging, and community by reinforcing team dynamics.

- Esteem Needs: Recognize achievements, assign important projects, and provide status to make people feel appreciated and valued.

- Self-Actualization: Provide challenging and meaningful work which enables innovation, creativity, and progress according to long-term goals. However, not all people are driven by the same needs - at any time different people in different social strata may be motivated by entirely different factors.

\section{Hypotheses}

The following hypotheses guided the study

1. Proactive personality traits will correlate significantly with transformational leadership style among workers.

2. Psychological empowerment will moderate the relationship between proactive personality traits and transformational leadership style among workers. 


\section{International Journal of Current Science Research and Review}

ISSN: 2581-8341

Volume 04 Issue 09 September 2021

DOI: 10.47191/ijcsrr/V4-i9-12, Impact Factor: 5.825

IJCSRR@ 2021

www.ijcsrr.org

\section{METHOD}

Three instruments were used in carrying out this study namely; proactive personality scale by Bateman \& Crant (1993), transformational leadership inventory by Podsakoff (1990) and psychological empowerment scale by Spreitzer (1995).

\section{Proactive Personality Scale (Bateman \& Crant, 1993)}

The proactive personality scale was developed by Bateman \& Crant (1993). It has 17-items. Some of the items include; I am constantly on the lookout for new ways to improve my life and if I see something I don't like, I fix it". The authors presented evidence for the scale's presented for the scale's reliability Cronbach alphas across three samples ranged from .87 to .89 and a testretest reliability coefficient of .72 over a 3 -month period. Bateman \& Crant utilized Likert scale response format ranging from "Strongly disagree to strongly agree", but they did not specify whether it was seven-point or five-point scales. However, for the purpose of ease of response, a five-point Likert response format ranging from " $1=$ strongly disagree to $5=$ strongly agree" will be adopted by the researcher. High score on the scale indicates high proactive behavior, while low score indicates low proactive work behavior. More so, Concurrent validity analysis will be conducted by the researcher to validate Bateman and Crant's (1993) proactive personality scale. The Concurrent validity of the scale was assessed by correlating scores of the proactive personality scale with Spreitzer's (1995) 12-item multidimensional measure of psychological empowerment in the workplace. Statistical analysis of the data yielded significant concurrent coefficient $(\mathrm{r}=.25, \mathrm{p}=.035)$.

\section{Transformational Leadership Inventory (Podsakoff, 1990)}

The Transformational Leadership Inventory was developed by Podsakoff et al (1990). The TLI consists of twenty three (23) items with six (6) dimensions: Articulating a vision, providing an appropriate model, fostering the acceptance of group goals, high Performance expectations, individualized support and intellectual stimulation. The authors utilized seven-point Likert scale ranging from $1=$ strongly disagree to $7=$ strongly agree. Podsakoff et al (1990) reported Cronbach's alpha reliability ranging from .80 to .90 , for the dimensions. Concurrent validity analysis was conducted by the researcher to improve Podsakoff et al.'s (1990) transformational leadership inventory (TLI). The concurrent validity of the scale was assessed by correlating scores of the transformational leadership inventory with Walumba, Avolio, Gardner, Wernsing and Peterson's (2008) 8-item Authentic Leadership Questionnaire (ALQ). Statistical analysis of the data yielded moderate and significant concurrent validity coefficient $(\mathrm{r}=.54, \mathrm{p}<.001)$.

\section{Psychological Empowerment Scale (Spreitzer, 1995)}

The psychological empowerment scale developed by Spreitzer (1995) was used to measure psychological empowerment. It is a 12item scale that measures the four dimensions of empowerment: meaning, competence, determination and impact. The instrument has four subscales of three items each, and each of the subscale measures a dimension. It was designed in a 5-point Likert - type response format that ranges from "strongly disagree $=1$ to strongly agree $=5$. Spreitzer's test-retest reliability analysis yielded a reliability coefficient of .72 for the industrial sample and .62 for insurance used in the study. Some of the sample items used in the study include; "the work I do is very important to me", "I am confident in my ability to do my job". The researcher got a Cronbach alpha of .87 from a pilot study, meaning that the instrument is valid for the proposed study.

\section{DESIGN AND STATISTICS}

The study is a survey study which adopted the correlational design as a study design; consequently multiple linear regressions were used as a statistical tool for data analysis.

\section{RESULTS}

Table 1. Summary of Means, Standard Deviations and Correlation Coefficients of Proactive personality, Competence, Self determination, Impact, Meaning dimensions of psychological empowerment Transformational leadership $(\mathrm{N}=210)$

\begin{tabular}{|c|c|c|c|c|c|c|c|c|}
\hline Variables & $\mathrm{M}$ & SD & 1 & 2 & 3 & 4 & 5 & 6 \\
\hline Transformational leadership & 125.77 & 51.49 & 1 & & & & & \\
\hline Proactive personality & 77.40 & 48.52 & $.33 * *$ & & & & & \\
\hline
\end{tabular}




\section{International Journal of Current Science Research and Review}

ISSN: 2581-8341

Volume 04 Issue 09 September 2021

DOI: 10.47191/ijesrr/V4-i9-12, Impact Factor: 5.825

IJCSRR@ 2021

\begin{tabular}{llllllllll} 
Competence & 12.88 & 2.27 & $-.27 * *$ & -.02 & 1 & & & \\
Self determination & 12.89 & 1.99 & $-.26^{* *}$ & -.05 & $.96^{* *}$ & 1 & & \\
Impact & 12.91 & 2.12 & $-.17^{*}$ & -.09 & $.56^{* *}$ & $.10^{* *}$ & 1 & \\
Meaning & 12.88 & 2.265 & $-.27 * *$ & -.02 & $.10^{* *}$ & $.96^{* *}$ & $.56^{* *}$ & 1 \\
\hline
\end{tabular}

Note, $* *=p<.01, *=p<.05 ; * *$ means that the test is significant at.01 level of significance.

The result in table one showed that proactive personality positively and significantly correlated with transformational leadership style at $\mathrm{r}=.33, \mathrm{p}<.01$. However, competence, self-determination, impact and meaning dimensions of psychological empowerment negatively and significantly correlated with transformational leadership style at $\mathrm{r}=-.27, \mathrm{p}<.01 ;-.26, \mathrm{p}<.01 ;-.17$, $\mathrm{p}<.05$; and $.27, \mathrm{p}<.01$, respectively. By implication, this implies that individual's with proactive personality trait is often enhanced increased by transformational leadership style. Also, as psychological empowerment decreases transformational leadership style further increases.

Table 2. Summary of moderated hierarchical Multiple Regression on the effect of Competence, Self-determination, Impact, Meaning dimensions of psychological empowerment on Proactive personality, and Transformational leadership

\begin{tabular}{|c|c|c|c|c|c|c|c|c|}
\hline Models & $\mathbf{R}^{2}$ & $\operatorname{Adj} R^{2}$ & $\Delta \mathbf{R}^{2}$ & DF & $\mathbf{F}$ & $\begin{array}{l}\beta \\
\text { (SC) }\end{array}$ & $\mathbf{T}$ & Sig \\
\hline Step 1 & .11 & .11 & .11 & $1(110)$ & $13.49 * *$ & & 11.32 & .000 \\
\hline Proactive personality & & & & & & .33 & 3.67 & .000 \\
\hline Step 2 & .18 & .15 & .07 & $3(108)$ & $7.66 * *$ & & 5.43 & .000 \\
\hline Proactive personality scale & & & & & & .325 & 3.71 & .000 \\
\hline Impact & & & & & & -.263 & .106 & .916 \\
\hline Meaning & & & & & & .05 & -2.50 & .014 \\
\hline Competence & & & & & & -.257 & -2.96 & .004 \\
\hline Self determination & & & & & & -.243 & -2.78 & .006 \\
\hline
\end{tabular}

Note, $* *=p<.01, *=p<.05 ; R^{2}=\mathrm{R}$ square; $\Delta=$ increase on adjusted $R^{2}$ and $F$-ratio as a result of the interaction; Adj $\mathrm{R}^{2}=$ Adjusted r square. $\beta(\mathrm{SC})=$ Standardized Coefficients Beta.

Table 2 presented the moderated hierarchical multiple regression analysis using an enter method. The result in step 1 revealed that proactive personality trait positively and significantly predicted transformational leadership style among workers at $F(1,110)=$ $13.49, p<.01 ;(\beta=.33, t=3.67, p<.01)$. Thus, hypothesis 1 was accepted. This indicates that employees with proactive personalities are more likely to have transformational leadership.

Similarly, step 2 showed that impact $(\beta=-.26, t=.11, p>.01)$, meaning $(\beta=-.05, t=-2.50, p<.01)$, competence $(\beta=-.26, t=-2.96$, $p<.01)$ and self-determination $(\beta=-.24, t=-2.78, p>.01)$ dimensions of psychological employment independently, negatively and significantly moderated the relationship between proactive personality and transformational leadership style among workers at $F(3,108)=7.66$. Furthermore, the interaction effect between proactive personality trait, all the dimensions of psychological empowerment accounted for negative significant variance than just proactive personality and transformational leadership styles alone, $\mathrm{R}^{2}$ change $=.07$ at $\mathrm{p}<.01$. Thus, hypothesis 2 of the study was rejected. This means that psychological empowerment inversely affected the transformational leadership style even among employees with proactive personality traits.

\section{DISCUSSION/CONCLUSION}

The result of table one showed that proactive personality positively and significantly correlated with transformational leadership style. Therefore, hypothesis one which stated that proactive personality traits will correlate significantly with transformational 


\section{International Journal of Current Science Research and Review}

ISSN: 2581-8341

Volume 04 Issue 09 September 2021

DOI: 10.47191/ijcsrr/V4-i9-12, Impact Factor: 5.825

IJCSRR@ 2021

Www.ijesrr.org

leadership style among workers was accepted. By implication, this implies that individual's with proactive personality trait is often triggered by increased transformational leadership style. This is in line with Farazja \& Khademi (2011) where he saw transformational leadership style as been highly conscious, morally engaging and even a spiritual process that provides developmental cubicle for organizations, through a reliable and equal power leadership.

In hypothesis two, the interaction effect between proactive personality traits, all the dimensions of psychological empowerment accounted for negative significant variance than just proactive personality and transformational leadership styles alone. Thus, hypothesis 2 of the study was rejected. This means that psychological empowerment inversely affected the transformational leadership style even among employees with proactive personality traits. Therefore, psychological empowerment did not moderate the relationship between transformational leadership style and proactive personality traits. This is against the findings of Amundsen \& Marinsen (2015) where he hinted that when employees are being psychologically empowered, their satisfaction level tends to boost. In the same manner, their belief of personal efficacy and ability to perform tasks are likely to result in higher satisfaction levels (Spreitzer et al; 1997; Hartline \& Ferrell, 1996). This variation may however not be unconnected with age and cultural differences existing between the two studies.

Leadership style in organizations has become very necessary that if the employees of organizations are not properly managed, can negatively affect the goal of any organization. Also, this study will enable organization management to have better insights into the causes of how to positively manage and bring out the best in their staff in order to aid the proper administration of the workplace/organization system and improve satisfaction.

Organizations are advised to employ transformational leadership styles as it is also a way of empowering the employees psychologically. It gives the employees great sense of belonging when they get to learn that their inputs count. More so, employees could exhibit more proactive traits inherent in them when they are led in manners that are best transforming.

This study was not carried out without some limitations. Basically, this study was limited to non-teaching staff of Nnamdi Azikiwe University Awka, Anambra State. Therefore, it is difficult for the results of the study to be generalized.

\section{SUGGESTIONS FOR FURTHER STUDIES}

Further studies on similar topic are encouraged to increase the sample size. Subsequent studies should go beyond the scope of this study and should be replicated in other locations in Nigeria.

\section{REFERENCES}

1. Avolio, B., Walumbwa, F. Gardner T., Wernsing, T. and Peterson, S. (2008). Authentic leadership: de authentic leadership: development and validation of a theory-based measure. Journal of Management 34(1), 89-126.

2. Bateman, T. S., \& Grant, J. M. (1993). The proactive component of organizational behavior: A measure and correlates. Journal of Organizational Behavior, 14: 103-118.

3. Bhatnagar, J., and Som, A. (2012), 'Lessons from two Indian Success Stories,' in Doing Business in India, eds. P. Budhwar and A. Varma, London: Routledge.

4. Conger, J., \& Kanungo, R. (1988). The empowerment process: Integrating theory and practice. Academy of Management Review, 13: 471-482.

5. Dekker, H., E. Oranje, P. Renooy, F. Rosing, and C. C. Williams (2010). Joining Up the Fight against Undeclared Work in the European Union. Brussels: DG Employment, Social Affairs and Equal Opportunities.

6. Enwereuzor I. K., Adeyemi B.A. \& Onyishi I. E. Trust in leader as a pathway between ethical leadership and safety compliance. Leadersh Health Serv. 2020;33(2):201-19.

7. Ergeneli, A., Ari, G. S., \& Metin, S. (2007). Psychological empowerment and its relationship to trust in immediate managers. Journal of Business Research, 60, 41-49.

8. Farazja, M., \& Khademi, M. (2011). The relationship between transformational leadership styles and interactionalist and attitudes towards organizational change. Journal of Educational Science, 6(4), 49-70.

9. Frese, M., Fay, D., Hilburger, T., Leng, K., \& Tag, A. (1997). The concept of personal initiative: Operationalization, reliability and validity in two German samples. Journal of Occupational and Organizational Psychology, 70, $139-161$. 


\section{International Journal of Current Science Research and Review}

ISSN: 2581-8341

Volume 04 Issue 09 September 2021

DOI: 10.47191/ijesrr/V4-i9-12, Impact Factor: 5.825

IJCSRR@ 2021

Www.ijesrr.org

10. Frohman, A. L. 1997. Igniting organizational change from below: The power of personal initiative. Organizational Dynamics, 25(3): 39-53.

11. Kirkman, B. L., \& Rosen, B. (1999). A model of work team empowerment. In R. W. Woodman \& W. A. Pasmore (Eds.), Research in organizational change and development, vol. 10: 131-167. Greenwich, CT: JAI Press.

12. Lucy L. Gilson \& Christina E. Shalley (2003). A little creativity goes a long way: an examination of teams' engagement in creative processes. Journal of Management, 30,(4) 453-470.

13. Podsakoff, P. M. (1990). Transformational leader behaviors and their effects on followers' trust in leader, satisfaction, and organizational citizenship behaviors. The Leadership Quarterly, 1(2), 107-142.

14. Rivai, V. (2011) Manajemen Sumber Daya Manusia untuk Perusahaan: dari Teori ke Praktik, Jakarta : Raja Grafindo Persada

15. Spreitzer, G.M. (1995). Psychological Empowerment In The Workplace: Dimensions, Measurement, And Validation. Academy Of Management Journal, 38(5), 1442-65.

16. Ugwu, F. O., Onyishi, I. E. and Rodriguez-Sanchez, A. M. (2014). Linking organizational trust with employee engagement: the role of psychological empowerment. Emerald, 46(3), 377-400.

17. Zhang, X., \& Bartol, K. M. (2010). Linking empowering leadership and employee creativity: The influence of psychological empowerment, intrinsic motivation, and creative process engagement. Academy of management journal, 53(1), 107-128.

Cite this Article: Iloke, Stephen E., Joe-Akunne, Chiamaka O., Joe-Akunne, Ikenna G., Ezeh, Leonard N. (2021). Relationship between Proactive Personality Traits and Transformational Leadership Style among Workers: Moderating Role of Psychological Empowerment. International Journal of Current Science Research and Review, 4(9), 1160-1166 